\title{
A(S) RESISTÊNCIA(S) AO GRANDE PROJETO NA AMAZÔNIA
}

\author{
Aluizio Lins Leal \\ Universidade Federal do Pará (UFPA)
}

\section{A(S) RESISTÊNCIA(S) AO GRANDE PROJETO NA AMAZÔNIA}

Resumo: A(s) resistência(s) ao Grande Projeto na Amazônia. O texto constitui-se em uma abordagem sobre o movimento do capital e as formas de resistência historicamente construídas na Amazônia brasileira, a partir do último quartel do século XIX, quando se inicia a caça às fontes de recursos naturais capazes de suprir a necessidade de matérias-primas para a formação de Capital pela atividade industrial, situação que perdura mesmo na atualidade com a hegemonia do capital bancário e a formação do capital financeiro.

Palavras-chave: Amazônia, capital, recursos naturais, formas de resistência.

\section{RESISTANCE TO THE BIG PROJECT IN THE AMAZON}

Abstract: The (s) resistances (s) to the Great Project in the Amazon. The text is in an approach to the movement of capital and forms of resistance historically constructed in the Brazilian Amazon, from the last quarter of the nineteenth century, when starting the hunt to sources of natural resources capable of meeting the need for raw materials for capital formation by industrial activity, a situation that continues even today with the hegemony of banking capital and the formation of financial capital.

Key words: Amazon, capital, natural resources, forms of resistance.

Recebido em: 16.02.2016. Aprovado em: 06.06.2016. 


\section{INTRODUÇÃO}

Há um determinante comum para o surgimento do Grande Projeto na Amazônia, que explica outros casos surgidos nela em outros períodos históricos - e, no caso da Amazônia brasileira, um caso emblemático. A base dêsse determinante são a fartura e a riqueza da Natureza regional, que transformaram a Amazônia em alvo histórico da ação colonial; a sua condição é a ascensão histórica do Capitalismo ao estágio do Imperialismo, cujo panorama econômico produziu uma pressão insuportável para que os espaços ricos de recursos naturais fossem abertos à exploração desenfreada para transformar êsses recursos em Capital.

Porisso, ao ser atingido o estágio histórico do Imperialismo, que resulta da ascensão hegemônica do capital bancário e da formação do Capital Financeiro, e da partilha do mundo pelas grandes economias capitalistas, se inicia, sobretudo no último quartel do século XIX, uma caça disseminada e febril às fontes de recursos naturais capazes de suprirem a necessidade de matérias-primas para a formação de Capital pela atividade industrial. $\mathrm{Na}$ Amazônia, esse recurso natural foi a borracha, que tornou-se o alvo das verdadeiras chusmas de cientistas-viajantes que choveram sôbre ela a partir de todo o século XIX, atraídos pela sua revelação por La Condamine (ainda nos meados do século XVIII), e confirmada por Humboldt (já nos finais do mesmo século). Sobretudo a partir da década de 1870 e até o comêço da segunda década do século XX (mais precisamente em 1911), vigeu na Amazônia um período gomífero que durou o tempo exato para que o colonialismo imperialista inglês, que precisava vencer os obstáculos materiais e econômicos próprios da Amazônia da época para obter a borracha a um custo compatível com as suas necessidades de formação de Capital, contrabandeasse as sementes da borracha para as suas possessões asiáticas e esfrangalhasse, a partir do cultivo ordenado da hevea, a frágil economia gomífera regional assentada no extrativismo. O exame dessa questão não cabe aqui, por não ser o escopo dêste trabalho.

Durante êsse período, o Capital empurrou para a Amazônia enormes hordas de especuladores e aventureiros de toda espécie, que, junto com uma oligarquia local inteiramente incompetente do ponto de vista burguês, contribuíram para estruturar uma economia gomífera assentada sôbre um sistema de trabalho escravo que se disfarçava sob a aparência do sistema de aviamento. Mas à parte isso, e seguindo a lógica do Capital, que tende a se expandir de modo irrefreável para as áreas ricas em riquezas naturais ainda livres das relações de produção capitalistas, consoante o explica a Lei GeraldaAcumulação Capitalista, de Marx, já afluíam aos trambolhões para a Amazônia - e, dentro dela, se espalhavam aos trambolhões por todos os seus cantos mais remotos - êsses indivíduos movidos pela sanha da busca de coisas preciosas da Natureza, naquêle momento representadas exclusivamente pela goma elástica.

O devassamento dos mais recuados espaços amazônicos, que representava um desafio material de vulto para êsses aventureiros, de um lado produziu empreitadas que encaravam o obstáculo do Rio e da Selva como impecilhos a serem transpostos a ferro e a fogo - como foi a tentativa (infrutífera) de construir, ainda em 1871, a estrada de ferro Madeira-Mamoré para alcançar os ricos espaços gomíferos fronteiriços entre o Brasil e a Bolívia e, de outro, criou localmente empreendedores de uma dimensão lendária,pois estavam animados da mesma intenção avassaladora de expansão que residia na mentalidade da burguesia britânica condutora da Revolução Industrial. O espaço peruano-boliviano produziu figuras como Antonio Vaca Diez, que navegou o Rio Orton (assim batizado em nome de um aventureiro natural dos Estados Unidos, James Orton (1870), que havia navegado êsse rio pela primeira vez,quando êle ainda se chamava Datimanu), Nicolás Suárez, de uma família de irmãos que colonizou o Alto Beni, e o irlandêsperuano Carlos Fermín Fitzgerald, popularizado como Fiscarraldo, personagem lendário do sistema fluvial Urubamba-Alto Beni-Madre de Dios, entre o Peru e aBolívia.

Como essa era a era em que a Técnica entrava no cenário como a grande pedra de toque para a Acumulação, as tentativas de converter a Amazônia, ainda naquêle período, em um enorme espaço produtivo em favor da formação de Capital, recorreram massivamente a ela. Esta foi a razão do recurso à estrada de ferro para vencer os trechos encachoeirados dos altos-rios (o caso da MadeiraMamoré), e à estrutuação do projeto produtivo autosuficiente e de grande porte assentado sôbre tecnologia avançada em áreas remotas, que, pela primeira vez, surgiu no Alto Beni sob o comando de Nicolás Suárez, na Cachuela Esperanza, representando para a Amazônia o modêlo disso que, mais tarde, viria a ser denominado justamente o Grande Projeto. Como naquêle momento os únicos grupos sociais existentes nas áreas sob o assalto das hordas invasoras eram os povos indígenas, o genocídio respondeu pela limpeza do espaço para a sua ocupação capitalista. Comentava-se que Nicolás Suárez, em apenas uma surtida, dizimara nada menos que 300 Karipuna. Por isso, não é possível ter restado qualquer registro da (inútil) resistência nativa à chegada do conquistador, coisa que, sem qualquer dúvida, deve ter havido; porém sob o silêncio da História - êsse relato oficial de legitimação dos direitos de usurpação dos territórios nativos pelo invasor, que, como sempre, contou ao seu modo e 
com tintura suave a saga da terrível e sangrenta ocupação do solo amazônico desde que por aqui pisou o primeiro colonizador. E como o Estado e a classe dominante sempre se fundem numa coisa só, nada restou que contasse a resistência dos nativos - com certeza heroica, anônima e trágica - à rapina dos seus territórios pela bota colonizadora.

\section{RESISTÊNCIAS AO GRANDE PROJETO NA AMAZÔNIA BRASILEIRA?}

Na Amazônia brasileira, o primeiro caso concreto de Grande Projeto surgiu aos finais da terceira década do século $X X$, sob uma forma inteiramente diversa, embora sob a mesma raiz uma necessidade produzida pelas condições do Imperialismo em fronteiras longínquas, que se lembrou que a Amazônia existia, para resolvê-la. A progressão do Imperialismo como etapa histórica colocou em confronto segmentos poderosos do capital monopolista. O automóvel, como o maior produto de consumo de massa da História, formatou um cartel com um poder extraordinário, que, à época, estava concentrado nas mãos dos capitalistas dos Estados Unidos, e, entre êstes, nas mãos de Henry Ford. Êsse cartel se ressentia da ação do cartel gomífero, em mãos inglêsas e holandêsas, já que os seus prêços de monopólio, encarecendo o custo dos pneus, encareciam o automóvel como produto, impedindo que o ramo automobilístico pudesse ampliar o seu mercado. Aproveitando um acidente de percurso histórico - o fim da Primeira Guerra Mundial - quando os estoques de borracha eram altos por serem estoques de guerra, o ramo dos automóveis recorreu, numa jogada de mercado, àquela velha fórmula típica da cultura dos Estados Unidos - a trapaça - para tentar tirar das mãos britânicas as suas plantagens, e os Estados Unidos derramaram no mercado os seus estoques para forçar uma baixa de preço da borracha e a falência da plantagem colonial gomífera britânica, que êles pretendiam comprar a prêço vil, para os seus fitos. Mas - os inglêses são os seus pais históricos, sobretudo nos valores culturais - a reação britânica neutralizou essa jogada, mantendo em suas mãos as plantagens, e - claro - mantendo os prêços que incomodavam o cartel do automóvel. Então, ajudados pelo apoio do seu Estado para conservar o seu poder de cartel, os capitalistas do automóvel procuraram (e expandiram-se para) espaços subordinados ao imperialismo do seu país na África e na América Central, nos quais montaram seus próprios projetos, para que produzissem borracha a prêços compatíveis com as suas necessidades de lucro, e, pois, de formação de Capital. Em obediência a essa demanda do imperialismo estadunidense, o govêrno brasileiro abriu inteiro espaço para que Henry Ford aqui instalasse um projeto moderno para produzir borracha em regime de monocultura, num território de um milhão de hectares que, a partir de 1928, se localizou às margens do Rio Tapajós, num local que, depois, ficou conhecido como Fordlândia.

Quando se examina se teria sido possível existir uma resistência regional a êsse projeto de raiz claramente imperialista, na Amazônia da época, constata-se ser ela, na prática, inteiramente improvável. A opinião pública do meio, formatada secularmente por uma colonização culturalmente castradora, eraumacoisaimbecil, formadaecultivada por uma imprensa - àquela época representada quase que exclusivamente pelos jornais - nas mãos de uma oligarquia econômicamente estúpida e incompetente, politicamente analfabeta por opção, culturalmente rasteira e formada pelas condições de classe herdadas da colonização, que administrava um atraso histórico aprimorado por práticas produtivas imemorialmente calcadas nas formas mais arcaicas de exploração da fôrça de trabalho regional, e, pois, avêssa à assimilação e ao cultivo do progresso científico e técnico ainda que admirasse, deslumbrada e passiva, os povos e países (principalmente os americanos e os alemães) em que êsse progresso se cristalizara em conquistas materiais que ela jamais conseguiria produzir ou impulsionar pelos seus próprios meios. Como consequência e sintoma dessa sua desnutrida capacidade técnica e da sua ignorância, limitava-se a formar blocos de admiradores - americanófilos e germanófilos -, que se reduziam a vibrar, como se fôssem torcidas de clubes de futebol, por um ou outro dêsses dois lados, com as realizações que ela jamais conseguiria concretizar. Se no Brasil, a essa época, já estavam sedimentados os elementos históricos básicos do atraso social - a associação conjugada da corrupção, desorganização e impunidade - na Amazônia isso se agravava por um ainda mais profundo degrau de subdesenvolvimento.

Pois foram (foi) exatamente êsses meios de comunicação - na verdade, pràticamente um só jornal (a Folha do Norte) -, sob o contrôle dessa oligarquia, que deram (deu) o tom da avaliação do projeto, trazido desde de fora e comunicado ao meio pelo segmento dominante - governantes, políticos e empresariado - noticiando a chegada consumada de um empreendimento que vinha para pilhar os recursos naturais da Região, recebendo todas as facilidades concedidas à rapina pelo Estado, no seu papel de instrumento de dominação de classe a serviço do interêsse do Capital, inaugurando um estilo de prática a ser seguido, daí por diante, em relação a todos os projetos de natureza similar na Amazônia, e instaurando, nela, ainda que bem antes da sua aparição histórica, o papel do Estado do Capitalismo Tardio. Assim, para essa oligarquia na verdade, uma subburguesia local - em processo de naufrágio, devido à sua incompetência, pela recessão que resultou do fim da economia extrativista da borracha, a vinda de um projeto dêsses era 
como que a própria salvação enviada pela divina providência, e ela tratou logo de apoiá-lo com todas as suas fôrças. As condições dêsse projeto - instrumento da rapina colonial e de destruição da Natureza -, nem de longe poderiam passar pelas considerações dessa subburguesia, sobretudo por dois dos motivos acima: pela sua fraqueza econômica, e pela sua incompetência, passividade e ignorância política, decorrentes da primeira. Por isso mesmo, o(s) jornal(is) local(is) (leia-se a Folha do Norte, cujo proprietário, Paulo Maranhão, era um dos mais destacados elementos dela) abriu espaço irrestrito para a colaboração da provinciana intelectualidade local, cujas loas ao projeto, ôcas e recheadas de um ufanismo subjetivo, escritas nos mais retumbantes tons do beletrismo bacharelesco, refletiam muito bem a inteira ignorância do meio a respeito da real natureza do empreendimento enquanto punham a nu a sua mediocridade e o seu analfabetismo político.

No entanto, houve uma meritória tentativa de resistência ao assim chamado Projeto Ford. Contrapondo-se às tacanhas fórmulas ideológicas do meio local, ela surgiu justamente por meio de duas pessoas cuja visão fugia dos antolhos dessa sociedade inculta e preconceituosa, e que logo foram convertidas em malditas pela rasteira intelectualidade do meio: Alberto Moreira e Orminda Bastos. Vejamos o que eu digo a respeito dos dois, com referência aos debates nos jornais locais sôbre o Projeto:

- Alberto Moreira era um jornalista do Rio de Janeiro, e seus artigos sôbre a questão eram frequentemente reproduzidos nos jornais locais, tendo ganho, pelas suas posições, o antagonismo dos defensores da chegada dos norteamericanos; o acusavam de ter preferência pelos alemães. Orminda Ribeiro Bastos era uma paraense em evidência pelas suas abertas posições sôbre os assuntos do momento, tendo se envolvido em diversas polêmicas, à época. O caso de Orminda Bastos é emblemático: paraense nascida em Manaus, formou-se em Direito em Belém, militou como advogada e jornalista, e é um marco no universo da luta pelos direitos da mulher. A sua lucidez e o seu descortínio colocam-na muito à frente do seu tempo. Intelectual (foi professora de grego e latim) e polêmica, nunca hesitou em defender as suas idéias com a fôrça de fundados argumentos. À época em que se envolveu nos debates relativos ao empreendimento Ford ainda era uma jovem (24 anos) intelectual destemida, e é notável a sua presença nêsses debates, porquanto no universo social daquêle momento, predominantemente masculino, polìticamente obtuso e culturalmente retrógrado, no qual o ranço machista provinciano reservava às mulheres o embotamento intelectual, além de - quando muito - o universo doméstico como espaço de ação, a única pessoa, entre todos os paraenses, a manifestar pùblicamente uma posição fundamentada, de inegável descortínio crítico sôbre o Projeto - e contrária à vinda dêle foi justamente uma mulher.

O resultado final e inevitável disso tudo foi a chegada, apoiada por êsse meio social estúpido, do Projeto Ford, cuja presença provocou as mais sérias consequências capazes de serem imaginadas por uma intervenção modernizadora sôbre uma região ainda - relativamente - intocada pela brutalização ambiental, embora já històricamente marcada pela brutalidade social da colonização. Como, devido à arrogância colonizadora que é própria de empreendimentos dessa ordem, se impôs dentro dêle, desde o seu primeiro momento, aos ingênuos cabôcos contratados para trabalhar na sua implantação, a mesma rigidez disciplinar que as Indústrias Ford impunham ao seu operariado urbano na Detroit industrial daquela época, houve severos choques culturais que resultaram na revolta dos simplórios nativos, logo sufocada pela milícia estadual, usando o que havia de mais moderno para êsse fim, à época, e na prisão dos - assim considerados - cabecilhas da resistência, levados para Belém e metidos na prisão sem que se saiba do seu destino final, e provàvelmente sem que soubessem, de facto, os porquês do que thes havia acontecido. Mas, antes mesmo disso, o clima da sua chegada e as tratativas que envolveram a concessão de um milhão de hectares a Ford em uma das áreas mais estratégicas do Estado e da Região, foram marcadas por um clima de corrupção em que se inseriram todas as formas mais modernas da chicana trazidas com a nova idade econômica. Os contôrnos dessa Corrupção Modernizadora aparecem associados à chegada à Amazônia de levas de estrangeiros a ela - quer do Norte, quer do Sul - sem que nisso se contasse a língua que falassem (inclusive a portuguêsa), pois foi um arrivista de São Paulo, Jorge Dumont Villares - que, provàvelmente, até a sua chegada sequer deveria saber onde e o que eram a Amazônia e o Pará quem primeiro se apresentou em Belém, logo que surgiram os primeiros rumores da vinda de Ford. E isso ainda foi azeitado pelas intervenções e figuras do governador do Estado, do Prefeito de Belém, de um coronel inglês a serviço de Ford e de Villares, chamado Greite, além de outros, envolvendo gorjetas, propinas, e um clima em tudo por tudo semelhante ao que hoje ainda se pratica exemplar e impunemente num país chamado Brasil. É tão rica mas também tão extensa - a história dêsse Grande Projeto e da corrupção a êle associada que se torna impossível aqui reproduzi-la, por mais tentadora que seja essa intenção. Êle teve um fim melancólico, devido a grosseiros êrros de concepção-inclusive os 
tocantes à compreensão da natureza regional - mas não sem antes deixar, nos rastros da sua passagem, as marcas das profundas alterações provocadas por êle sôbre o meio natural e social.

O próximo Grande Projeto que aparece na Amazôniajácheganorastrodamaisnovarapinasôbre os recursos naturais amazônicos - a rapina sôbre os recursos minerais -, associada à idade industrial do pósguerra. Como a Segunda Guerra Mundial foi o marco de diversas e profundas mudanças sôbre o próprio sistema de poder do Capitalismo a nível planetário, incluindo a recomposição do Mercado Mundial e a hegemonia absoluta do imperialismo dos Estados Unidos sôbre o resto do mundo, a não destruição da União Soviética na guerra, como o queriam os planos capitalistas, era uma pedra no sapato dêsse projeto. Em resposta a isso, os Estados Unidos impuseram a Guerra Fria, como substituto à permanente e implacável contenção pelas armas das tentativas libertárias de caráter socialista que se haviam multiplicado pelo mundo logo após a guerra - sobretudo entre os povos submetidos pelo guante do feroz colonialismo imperialista. Assim, os Estados Unidos logo tomaram a providência de formatar um projeto de poder mundial que pressupunha armaremse até os dentes - o que começou com a bomba atômica, mandando um recado de fogo a qualquer rebeldia à sua ordem -, e criando uma fôrça armada que exercesse o papel de polícia mundial, impondo o terror da destruição e a ameaça da guerra a quem Ihes desobedecesse, tal qual o fazem até hoje.

Isso envolvia, inevitàvelmente, o contrôle de, naquêle momento, todo qualquer recurso mineral que pudesse ser usado para a produção pesada - que signficava navios, tanques, canhões, e armamento e equipamento pesado em geral - nas mãos das suas emprêsas industriais, ou seus aliados, controlados por êles. Isso subentendia, pois, o contrôle de qualquer mineral que se ligasse à produção do aço. E êsses minerais eram principalmente dois: o ferro, e o manganês - êste último usado para depurar a qualidade do ferro, retirando dêle as impurezas do enxôfre para permitir a produção de ligas de aço de alta qualidade.

Desgraçadamente, êsse mineral existia na Amazônia. No então Território Federal do Amapá. $\mathrm{E}$ em quantidade e qualidade insuperáveis. Era, naquêle momento, o melhor manganês do mundo.

Como o Brasil já era, então, de fato, um país atrasado e retardatário, desconhecia por completo essa sua jazida extraordinária. Mas o Serviço Geológico dos Estados Unidos (USGS), não. Como entre as condições do atraso estão a livre e inteira permissão de entrada e trânsito de quaisquer cientistas ou acadêmicos dos países amigos e desenvolvidos nos países retardatários em nome da Ciência, essa jazida já era conhecida dêles, e o mapeamento geográfico da mesma - isto é, dos rios que limitavam a área de ocorrência dela, desconhecida dos brasileiros -, já estava muito bem feita por êles. Assim, quando os primeiros geólogos chegaram ao local dela (sempre os brasileiros perfazendo funções acólitas para os norteamericanos), foram os mapas do USGS a dar a referência do local e da localização do corpo geológico.

Mas antes é bom que se examinem alguns outros fatos: isso ocorre em 1945. E ainda em 1943, no govêrno de Getúlio Vargas, no rastro dos Acôrdos de Washington, que estabeleceram a obrigatoriedade, dolado do Brasil, do fornecimento de borracha e ferro aos EUA para as suas necessidades de guerra, foram criados os chamados Territórios Federais, alegando-se que eram necessários para maior agilidade administrativa, muito embora quase nada, na prática, pudesse justificar essa alegação. Por serem considerados territórios estratégicos para a segurança nacional, todos êles foram colocados sob a direção de interventores militares. Para o Amapá foi designado como interventor o então capitão do Exército Janary Gentil Nunes. Todos os territórios federais se localizavam em regiões remotas, e nenhuma providência maior foi tomada que justificasse as razões alegadas para a sua criação, muito embora dois dêles apresentassem aspectos curiosos, que pareciam justificar isso: o de Fernando de Noronha, criado ainda um ano antes, em 1942, foi logo destacado como base avançada de guerra, e colocado à disposição da marinha dos EUA; e o Amapá, que, continuava a ser uma área longínqua e isolada, foi dotado, sem qualquer motivo aparente, de um serviço geológico, gerido por Fritz Louis Ackermann, um alemão, engenheiro de minas e prisioneiro de guerra. Imediatamente uma multinacional dos EUA, a Hanna Mining, aterrissou lá e começou a pesquisar ferro no Rio Vila Nova.

Sùbitamente, comoquedonada, começaram a enxamear por lá os geólogos do USGS, como se tivessem tido uma revelação noturna e sobrenatural, durante o sono, de que existiam alí grandes riquezas minerais. E logo o capitão-interventor, como que mostrando que entrava decidido na dança dessa mágica, fêz proclamar a todo o Território que daria um prêmio a quem trouxesse provas materiais da existência de manganês. Pronto. Estava confirmada a natureza da Revelação. Assim, um cabôco chamado Mário Cruz, que era regatão, trouxe até o governador uma pedra azulada que usava como lastro para a sua canoa, que catara no chamado Morro do Chumbo, próximo da Serra do Navio, no Rio Araguary.

Mais uma vez, Pronto. Estava decretada a definitiva versão histórica até hoje repetida ad nauseam sôbre a descoberta do manganês no Amapá.

Como capitão, e nacionalista, Janary, que acreditava na tese segundo a qual era viável e seria possível montar um projeto de desenvolvimento 
capitalista nacional conduzido pelo Estado, tida como dogma pelos militares, logo tomou providências para a exploração daquela riqueza. Formou uma comissão de notáveis do Amapá da época, que elaborou o esbôço de uma emprêsa paraestatal, cujas ações seriam postas à venda nos Estados amazônicos e seria administrada pelo poder público federal, para montar o projeto mineiro. Mas esta intenção foi atropelada no nascedouro pelos interêsses imperialistas e pelos indivíduos encarregados de defendê-los. E logo se passou à tomada das providências necessárias para que o minério passasse ao contrôle da emprêsa privada, ao lado de que o panorama internacional daquêle momento, marcado pelo surgimento da Guerra Fria como estratégia de contenção à União Soviética e aos projetos libertários que começavam a surgir no cenário do pósguerra exigia que chefes de Estado rebeldes fossem sumàriamente derrubados, para que o projeto de reorganização da Economia Mundial Capitalista não sofresse solução de continuidade.

Como o Brasil era estratégico para êsse fim, Getúlio, que tinha uma política de independência produtiva e soberania política não era tolerado pelos Estados Unidos, que o queriam fora do poder, e o depuseram, num golpe articulado pelo subsecretário de Estado, Spruille Braden, e pelo seu embaixador no Brasil, Adolf Berle Jr. Participaram direta e decisivamente nisso (da articulação e execução do golpe), dois generais brasileiros recém-exsimpatizantes do Nazismo - Góis Monteiro (que o executou) e Eurico Gaspar Dutra, que foi alçado à condição de presidente. O govêrno de Dutra é entendido por historiadores como Moniz Bandeira (1978) como um prelúdio, em tudo por tudo, dos govêrnos da Ditadura que se seguiu ao golpe militar de 1964, aí incluídas a repressão brutal contra a classe trabalhadora (inclusive o metralhamento e o assassinato em praça pública de manifestantes), e a canina subserviência fardada às ordens do imperialismo dos EUA, cujos representantes (três dêles), funcionários de Estado ou de multinacionais, acompanharam às abertas a elaboração da Carta Magna brasileira de 1946, pressionando os constituintes por dispositivos que atendessem os interêsses dos EUA e das suas emprêsas monopolistas.

Foi nêsse clima que se providenciou que indivíduos que pertenciam ou aos quadros do serviço público ou da emprêsa brasileira que guardassem afinidade ideológica e/ou interêsses individuais com o sistema capitalista - e, particularmente, com essa situação -, fôssem colocados nos lugares certos nos postos ou nas instituições estratégicos dêsse processo -, para que pudessem corromper as bases do projeto de exploração sob contrôle nacional, e garantissem a sua entrega às mãos da emprêsa privada estrangeira. Destacam-se particularmente nêsse mister dois indivíduos: Glycon de Paiva e
Augusto Trajano de Azevedo Antunes. O primeiro foi infiltrado - pode-se afirmar assim - como parecerista sôbre a exploração do minério logo após a descoberta dêle, tendo sido enviado ao Amapá para acompanhar todo o processo como engenheiro de minas do Departamento Nacional de Produção Mineral, e membro do Conselho Nacional de Minas e Metalurgia. A sua designação já era o fruto do dedo invisível da emprêsa rapineira, através dos seus serviçais no interior da estrutura do serviço público, mexendo as peças do xadrez para que tudo desse certo a favor do seu interêsse - pois as qualificações dêle o faziam o elemento ideal para ser metido no processo, e, uma vez dentro dêle, fazer relatórios e emitir pareceres que tivessem fôrça de competência para orientar as decisões sôbre o caso. E êle o fêz fundamentando as suas recomendações naquela arenga proposital que prepara muito bem a entrega da riqueza natural para a rapina: enaltecendo a enorme oportunidade que surgia para o Brasil com a descoberta de um mineral tão estratégico - e, para que se pudesse aproveitá-lo com a devida eficiência, era necessário que se entregasse a sua exploração à iniciativa privada.

O segundo movimento da jogada fica por conta da chegada ao Amapá de um obscuro empresário de Minas, justamente Azevedo Antunes, que vinha examinaro desafio que eram as condições da empreitada. Antunes vinha quase como anônimo mas trazia escondida por trás dêle a real articuladora de tudo, a Bethlehem Steel, beneficiada por todas as medidas do Estado (e, particularmente, do govêrno de Dutra), e já inteiramente preparada para pôr as unhas no riquíssimo manganês do Amapá. Daí por diante, jogou-se no lixo o projeto da emprêsa estatal, veio do govêrno federal a ordem para que se procedesse a uma licitação para a exploração privada do minério, conforme recomendava Glycon de Paiva (1946), e o obscuro empresário Azevedo Antunes venceu uma licitação contra dois poderosos concorrentes, para, um ano depois, concluir que a empreitada estava além das suas forças - e, através da intercessão do irmão do governador, o deputado federal Coaracy Nunes, solicitada em regime de urgência e em nome dos altosinterêsses nacionais (agora coincidentes com os da grande emprêsa interessada), obteve permissão do Congresso e da Presidência da República, para que a sua emprêsa, a até então quase desconhecida Indústria e Comércio de Minérios (ICOMI) se associasse a uma grande emprêsa que poderia lhe garantir mercado. A Bethlehem Steel. Tudo se consumou como previsto. As tentativas de resistência a êsse descarado roubo, como já acontecera antes (e iria acontecer em todos os casos a surgirem no futuro), trombou, desde logo, com a defesa organizada do Progresso para o Amapá nas figuras do Projeto, do empreendedor privado, dos Estados Unidos, e da Guerra Fria. As epígrafes dos jornais da época, 
ainda em grande parte do Pará, de cujo território o Amapá havia sido desmembrado, refletiam isso: Amostras de Minérios do Amapá em Exposição nos EUA; O Amapá Está Apto a Fazer a Independência Econômica do Brasil; Interesse Internacional Pelo Manganês do Amapá; A Fome de Manganês dos Estados Unidos; A Civilização Atravessa a Foz do Amazonas; Poderá o Brasil Tornar-se o Maior Fornecedor de Manganês aos EUA (As Remessas da URSS Diminuem); O Surto de Progresso Em Que Entrará o Amapá Será Simplesmente Prodigioso; Os Metais Estratégicos (O Programa e Defesa dos EUA e os Metais Estratégicos da América Latina). O tom altissonante dêsses títulos dá bem uma ideia de o quanto o panorama geral da Região, embora houvesse mudado substancialmente, continuava exatamente o mesmo que o da época do Projeto Ford.

Contudo, não se pode deixar de referir um pouco mais a respeito dêsses dois privilegiados atores dessa peça: Glycon de Paiva e Azevedo Antunes, que se haviam tornado amigos diletos não apenas pela incidentalidade que os uniu no caso do manganês; a sua identificação recíproca ia muito além disso, e com certeza foi um dos elementos que os juntou na campanha do Amapá; na verdade, o que mais os uniu - e consolidou essa união - foi a sua identidade ideológica. Menos de duas décadas depois, a articulação do Golpe Militar, no Brasil, sob a batuta do embaixador Lincoln Gordon e de um coronel (depois general e diretor da CIA) chamado Vernon Walters, mandado para o Brasil para fazer a articulação do golpe, pois era fluente em português e íntimo da quase totalidade dos generais golpistas, pôs novamente os dois, lado a lado, como destacados conspiradores. Azevedo Antunes, a essa época, já guindado à condição de grande empresário devido à sua importância como testade-ferro para a Bethlehem e da ICOMI como grande emprêsa do setor mineral, participou de um semnúmero de células, e agiu como um dos grandes arrecadadores de fundos entre o mundo golpista empresarial. Já Glycon de Paiva (1946) tornou-se assessor do golpe militar chileno, e é célebre uma frase de sua autoria: já ficou provado que a receita [a preparação do Golpe] funciona; basta colocá-la no forno.

Assim, as resistências a essa pilhagem não conseguiram ir além dos ecos, tamponados à fôrça, pela imprensa e pelo sistema, da lucidez indignada dêsses opositores, que deveriam ser mantidos no escuro. Álvaro da Cunha (1962), um bravo intelectual amapaense, produziu um libelo, Quem explorou quem no contrato do manganês do Amapá, denunciando essa tramóia urdida pelo banditismo imperialista dos Estados Unidos sôbre patrimônio do povo brasileiro, assim como o poder corruptor da multinacional - pois acusou Janary Nunes de tibieza ao ceder ao poder dela, bem como seu irmão,
Coaracy, de ter-se convertido em serviçal da mesma ao encaminhar o pleito de Azavedo Antunes para consumar a trapaça.

Assim, também, Marco Antônio Mastrobuono e Ladi Biezus, no Sul, manifestaram-se advertindo para o caráter brutalizador da exploração realizada pelos animais de rapina que são essas emprêsas, mostrando como a voracidade delas havia exaurido por completo as - até pouco tempo antes - ricas jazidas cubanas, quando Cuba, tomada à Espanha por um dos mais truculentos agentes do banditismo imperialista dos Estados Unidos, Theodore Roosevelt, ainda não havia sido libertada, pela sua Revolução, da condição, à qual o imperialismo dos ianques a havia convertido - a de quintal sujo (e Havana, de maior prostíbulo) dêsse imperialismo. Porém, apesar de suas bravas tentativas de resistência, nenhum dêsses lutadores conseguiu romper a pesada barreira da estupidez da opinião pública local, criada e mantida pela imprensa e pelo sistema.

Dêste modo, em mais ou menos 35 anos a ICOMI retirou mais de 30 milhões de toneladas de um minério tão rico que ao entrar no circuito comercial aumentou, de pronto, o teor mangânico médio do Mercado Mundial em 8 a 12\%. E ao exaurir a mina, retirou-se, lá deixando apenas os buracos. $E$ - Amapá de hoje, à parte a capa da modernização que falsifica a realidade social nos espaços do atraso, continua apresentando uma miséria social terrível, para a qual o saque perpetrado pela ICOMI contribuiu vigorosamente. Um famoso jornalista paraense costumava referir, nas suas palestras, que havia no Texas uma montanha feita com o manganês do Amapá, coisa evidentemente irreal, não só pelo tamanho material da coisa como pelo fato de que, em paralelo à necessidade de contrôle do minério como material estratégico e o seu uso industrial para fins militares, a lógica do Mercado mandava que, como mercadoria, êle fôsse vendido para quem pudesse tornar-se um seu consumidor, não importando de que quadrante fôsse - e assim, entre os compradores dêle estavam vários países do Leste europeu, a essa época pertencentes ao chamado bloco socialista. Mas, abstraindo-se do caso os excessos analíticos e as informações que aproveitam o desconhecimento geral, foi assim que o caso foi.

Os próximos Grandes Projetos surgiram, e em grande número, durante a Ditadura Militar. As razões da eclosão da Segunda Guerra Mundial como conflito interimperialista mostraram ao sistema capitalista a necessidade de prevenir a sua tendência autodestrutiva, exibida em duas guerras mundiais, e reorganizar o Imperialismo procurando evitar a ferocidade das disputas das grandes burguesias monopolistas pelo contrôle do Mercado Mundial. O final dêsse conflito havia exibido uma destruição de Capital tamanha que comprometia a 
própria essência do sistema, quer pela perda dêsse Capital, quer pelo esfrangalhamento da sua unidade política. E o rescaldo da Guerra mostrava a terrível razão disso: em primeiro lugar, a necessidade de recuperação das maiores economias capitalistas devastadas pelo conflito; e, de par com isso, a necessidade da reorganização do Mercado Mundial e da Economia Mundial Capitalista em novas bases, para que se evitasse a possibilidade de que as disputas capitalistas levassem, pela sua própria natureza, à própria destruição do seu sistema. As medidas tomadas nêsse sentido, marcadas pela hegemonia absoluta do imperialismo dos Estados Unidos como regente do mundo, fundaram-se de um lado na criação de organismos mundiais encarregados de reger o funcionamento geral do sistema (Organização das Nações Unidas (ONU), Banco Mundial (BM), Fundo Monetário Internacional (FMI), Acordo Geral de Tarifas e Comércio (GATT) [depois OMC]) e Organização do Tratado do Atlântico Norte (OTAN), e, de outro, na adoção da estratégia de mundialização da sociedade de consumo de massa para evitar (sem sucesso, devido à ação da tendência declinante da taxa de lucro, estimulada justamente pelo consumo de massa) o surgimento de novos mecanismos depressivos, e, pois, do ressurgimento de novas tendências destrutivas através daguerra.

Isso levou de um lado, à criação de uma nova Divisão Internacional do Trabalho (DIT) marcada pela industrialização de novos espaços que, antes da guerra, ainda estavam no estágio de economias agrárias, e a sua inclusão, nesta nova condição, ao Mercado Mundial Capitalista; e, de outro, à formação de um bloco mundial capitalista ao qual fossem incluídos êsses novos espaços, para que se excluíssem da economia mundial todos os países e povos que tivessem procurado seguir o caminho do Socialismo, colocando-os em um cêrco econômico e político cuja finalidade era expurgar qualquer alternativa não-capitalista à ordem mundial, agora controlada pelos Estados Unidos como o único a ditar as regras do Sistema. O Brasil foi incluído a essa nova ordem como uma economia capitalista de industrialização retardatária, industrialização essa que não visava beneficiar o país ou o seu povo - mas sim obrigá-los ao cumprimento de tarefas produtivas, dentro dessa nova DIT, que contribuíssem para maior agilidade na formação do Lucro, e, pois, da acumulação de Capital.

Ocorre que o govêrno de Getúlio havia se acompanhadodeumacampanhapelaautosuficiência produtiva e, pois, pela soberania política, numa onda nacionalista que criava obstáculos à livre imposição dos projetos da reorganização mundial do sistema capitalista, cujos agentes seriam as grandes emprêsas multinacionais. Essa resistência nacionalista, que havia sido a razão da deposição de Getúlio em 1945, ainda permanecia latente nas camadas esclarecidas da sociedade brasileira - com ênfase nas camadas estudantis e parte significativa dos representantes políticos - o que criou resistências à imposição de um poder absoluto para as emprêsas que eram os polos da industrialização, todas elas multinacionais. A resposta imperialista, a exemplo do que aconteceu em todos os lugares onde apareceram entraves à imposição dêsse projeto, foi a articulação de um golpe político que retirasse do poder os grupos rebeldes, colocando em seu lugar o pessoal politicamente fiel ao projeto imperialista. $E$, também, a exemplo do que iria acontecer nos outros lugares, a campanha pela derrubada dos recalcitrantes se apoiou, sempre, na aparição de uma feroz campanha ideológica identificando os resistentes com o Comunismo, do qual se fazia uma imagem satânica, produzida pela lavagem cerebral como técnica de ação da Doutrina da Segurança Nacional, um catecismo ideològicamente deformador que havia sido disseminado em todos os cantos do mundo acompanhando a expansão imperialista dos Estados Unidos. Essa Doutrina é uma doutrina da segurança dos Estados Unidos mas sempre foi ideològicamente difundida como a Doutrina da segurança do falso Mundo Livre apoiada pela demonização da imagem do Comunismo e dos comunistas. A fôrça do seu argumento está em ser propositalmente rasteira, para poder ser tanto melhor assimilada e aceita quanto mais ignorante ou mais fanatizado fôr o meio. E dêste modo ela criou clientelas privilegiadas, das quais sempre se sobressaíram os militares. A hierarquia e a disciplina, bases da estrutura e do comportamento militar, sempre fizeram do militar um simpatizante nato do regime autoritário - e a ordem unida da mentalidade militar sempre os tornou receptores fáceis de ideologias como essa, que propõe a adoção de soluções de fôrça e a imposição de ditaduras em nome da Democracia. É por isso que todos os golpes políticos impostos nesse período o foram pelos militares, todos adotavam como orientação os princípios da Doutrina da Segurança Nacional, e todos eram ferozmente anticomunistas, e aliados aos Estados Unidos como grande representante da Democracia.

A imposição da Ditadura pelo golpe militar brasileiro, portanto, teve como tarefa fundamental assegurar a inserção da economia brasileira à nova DIT sem maiores resistências, e, dentro desse propósito, cumprircom todosos objetivos particulares e pôr em prática todos os projetos ligados a ela. E o mais precioso deles era pôr a Amazônia ao alcance direto do Capital. E como a estupidez produzida na mentalidade militar latinoamericana - sobretudo na brasileira-pela Doutrina da Segurança Nacional, que, como catecismo imperialista, tinha como finalidade deformar ideològicamente os seus leitores a favor de um alinhamento submisso com os interêsses dos Estados Unidos, os militares da Ditadura brasileira 
conduziram a ocupação da Amazônia envergando uma falsa premissa (a de estarem protegendo a Região contra um inimigo na realidade inexistente), enquanto, através dos projetos que gestaram sobre ela, entregaram as suas riquezas - ou a entregaram inteira, e de modo canino - nas mãos do verdadeiro inimigo do seu povo, que era travestido, pela Doutrina, de amigo e aliado histórico.

Foi assim que, consolidadas as medidas iniciais de ajustamento político da sociedade brasileira à nova ordem, o regime fardado passou, imediatamente, à ocupação da Amazônia. Devido ao tamanho e à natureza da Região, e das riquezas de ordem estratégica envolvidas pela sanha capitalista do momento histórico, o Grande Projeto era, instintivamente, o instrumento adequado para a exploração dessas riquezas. E como foram igualmente grandes a multiplicidade e diversidade dos mesmos, não é possível, aqui, se deter analìticamente sôbre cada um dêles, que, pelas circunstâncias, estavam já inteiramente preparados de antemão, dada a rapidez com que foram gestados e postos em ação para as finalidades que tinham.

À parte o rançoso capítulo da colonização da Amazônia pela pata do boi, iniciado ainda pela compadragem mineira do período juscelinista e prelúdio travoso da sua atual devastação pelo agronegócio, o filet mignon que provocava a ambição do grande capital residia nos minérios e nas oportunidades de mercado para as chamadas comodities, êsse rótulo genérico que é dado a toda mercadoria estratégica para a Acumulação. E assim a Ditadura abriu espaço irestrito para a atuação do grande capital minerador - começando pelo Código Brasileiro de Mineração de 1967 -, que permitiu o livre assalto às maiores riquezas minerais da Amazônia. Dêste modo, os grandes projetos que se assentaram nela a partir da Ditadura - exceto um, que já se assentava quando eclodiu o Golpe - foram para saquear a melhor bauxita do mundo àquela época, no Rio Trombetas (Mineração Rio do Norte, 1975), em Oriximiná, destinada a extrair o minério do alumínio; o projeto metalúrgico associado a ela, a ALBRÁS/ALUNORTE, em Barcarena, para produzir alumina e alumínio primário; e, para o funcionamento desta, que foi criada para atender às necessidades de transferir a grande maior parte do parque japonês de produção de alumínio para outras fronteiras, devido ao custo energético provocado sôbre o Japão pela crise do petróleo, surgiu mais um outro Grande Projeto, o da usina hidroelétrica do Tucuruy, no município do mesmo nome, para entregar a energia lá gerada ao complexo ALBRÁS/ ALUNORTE com um prejuízo de ao redor de $37,5 \%$ sôbre o custo de produção.

Os outros grandes projetos dêsse período foram a ICOMI, que já existia, rapinando todo o manganês do Amapá, a JARY (o único projeto poliprodutor da Amazônia, que estava em processo de criação ao eclodir o Golpe) - um complexo que contêve nêle cinco projetos diferentes: produção de arroz, plantio e produção de celulose, mina, extração e beneficiamento de caulim, extração e produção de bauxita refratária, e criação de bufalinos, ocupando, originalmente, uma área de mais de um e meio milhão de hectares, e derrubando mais de cem mil hectares de floresta só para a plantação monocultora para celulose $\mathrm{O}$ seu proprietário era um aventureiro estadunidense, Daniel K. Ludwig, que possuía um império formado por atividades que iam desde uma gigantesca frota de petroleiros até rêdes de hotéis, motéis e casas de jôgo no México e nas Bahamas, o que - comentava-se - o colocava na suspeita condição de estar associado às rêdes de lenocínio e prostituição, tão comuns e ainda mais graves nos países retardatários - o que não o impedia de ser consultor do govêrno dos Estados Unidos, e empresário privilegiado junto à Ditadura Militar brasileira, possuindo a rara deferência de, quando no Brasil, ir até o general-presidente do momento sem que precisasse marcar consulta. Por fim, o Grande Projeto dos Carajás, que continha, segundo as medições da época, uma jazida de ferro de 18 bilhões de toneladas, além de ser uma província mineral - continha outras enormes jazidas de cobre, manganês, bauxita, níquel e estanho.

Nenhum dêsses projetos - exceto a ICOMI no período anterior à Ditadura - pôde ser objeto de resistência. A feroz repressão que o regime militar impôs sôbre a sociedade brasileira, impediu qualquer manifestação, por tímida que fôsse, contra êles. O que aconteceu - mas não especìficamente contra qualquer um dêles - foram reações isoladas, no interior de associações de categorias profissionais, como a dos geólogos, contra a pilhagem que se desenhava contra o patrimônio mineral brasileiro a partir da edição do Código de Mineração de 1967, ou contra a avidez da Meridional, filha da United States Steel, sôbre o cobre dos Carajás, ou, ainda, reações do meio acadêmico contra a natureza de projetos como o do Tucuruy, da ALBRÁS/ALUNORTE, e até da Mineração Rio do Norte, nos quais a Companhia Vale do Rio Dôce (CVRD), ainda paraestatal, era usada como um mineroduto de recursos públicos para entregar nas mãos dos sócios privados do grande capital benefícios financeiros além dos que êles já faziam jus diretamente, da parte do govêrno. Vale ressaltar que, ainda durante esse período, a Ditadura ainda procedeu a verdadeiras esbórnias garantidas pelo tacão da bota fardada, como oito milhões de dólares de renúncia pelos Incentivos Fiscais (valores da época) à ICOMI, para criar uma fábrica de pelotização de finos projetada e fabricada nos Estados Unidos, e que se destinava a raspar o farelo do extraordinário manganês do Amapá, de um altíssimo teor mangânico, que os métodos tradicionais de extração não haviam conseguido retirar, para pelotizá-lo e exportá- 
lo, levando daqui até a última grama do minério, coisa que era apresentada, com um orgulho cínico, como uma extraordinária conquista técnica. Nada disso podia ser contestado, pôr fôrça da repressão feroz da ditadura. Isso não impediu, porém, que os movimentos de oposição ao Regime Militar, jáquando êle começava a cair de pôdre, convocassem, no Congresso, um Seminário sôbre o Grande Carajás, que o examinou e denunciou como um crime de lesapátria - sem resultados práticos, porém, porquanto o Capital Financeiro, apoiado pelo cêrco ao Brasil endividado pelos militares, policiado pelo FMI, impôs condições duríssimas à implantação do Projeto, que resultaram ao país não só um endividamento ainda maior, como garantiram a entrega do minério aos seus controladores em condições humilhantes.

Como arremate do caos que o regime fardado instaurou na Amazônia, ainda se passou um outro desfêcho - parcial -, no universo dos Grandes Projetos: aJARY entrou em colapso, por Ludwig, cuja figura autoritária não aceitava qualquer negativa, ter sido contrariado, pela primeira vez, nas exigências que sempre havia feito e visto serem atendidas pelo Regime. Como a Ditadura já estava na sua fase final, e agora grupos antagônicos se digladiavam no interior do próprio poder militar, e como o completo fracasso dos projetos dela começava a se apoiar em remendos de urgência, e como um dêles dizia respeito ao problema agrário, a solução, como sempre, foi aprofundar a militarização do caso e, na Amazônia, a questão agrária passou a ser comandada por Grupos Executivos, submetidos a uma autoridade militar, em cada área respectiva. Um dêsses foi o GEBAM, o Grupo Executivo de Terras do Baixo Amazonas, comandado por um almirante - Gama e Silva - que pertencia a uma facção militar cujo comandante havia sido pôsto em desgraça por ser adversário de um outro, do qual Ludwig sempre havia recebido todas as facilidades e privilégios. Êsse almirante, então, resolveu enfrentar o poder até então absoluto de Ludwig, negandoIhe permissão para construir uma hidroelétrica particular na Cachoeira de Santo Antônio - coisa que Ludwig contava como certa, embora fosse ilegal ante a legislação brasileira -, e que deveria reduzir o seu custo de produção de celulose, para competir no mercado europeu. Enfurecido pela audácia do almirante, Ludwig, em manobra típica do banditismo empresarial, resolveu chantagear o Regime e deixou de pagar os compromissos financeiros da fábrica de celulose, que o Banco Nacional de Desenvolvimento Econômico e Social (BNDES) havia avalizado e teve que pagar, criando um impasse para um país endividado ao impossível, o que fêz com que os militares tivessem que procurar um substituto para assumir o Projeto, o que, porém, dependia do humor de Ludwig, que tinha a palavra decisiva nessa escolha, tendo eleito como seu sucessor Augusto Trajano de Azevedo Antunes, a ave de rapina do manganês amapaense, que, após a ICOMI, ainda exauriu a JARY até o zero absoluto, agora sob a administração dos seus netos, que a acabaram vendendo ao empresário Sérgio Amoroso, de São Paulo, por um dólar, tamanhos eram o passivo e os problemas de um projeto gigantesco como ela.

Após a Ditadura e com a imposição da Democracia Civil, essa pilhagem não sofreu solução de continuidade, porque se modificou a cara do regime político, mas não as relações do Estado brasileiro com o Imperialismo, o que, agora, continuava assegurado por novas formas de adesão, do empresariado e dos políticos armados com a corrupção e a impunidade - que os militares haviam proclamado que tinham vindo sanear, mas, ao contrário, haviam agravado ainda mais -, aos interêsse e ditames imperialistas.

Êsse período convive com a imposição, no Brasil, das mudanças provocadas pela necessidade de readaptar o sistema capitalista à crise que já começava a se desenhar no panorama global desde a década de 1970, e que ameaçava, mais uma vez, a estabilidade dêle. Assim, a onda da globalização, acompanhada nos países atrasados pela sua corolária, a onda privatista, atingiu em cheio as condições de funcionamento de uma economia já combalida pelas terríveis medidas da Ditadura, e agravou ainda mais a pressão pela entrega dos recursos naturais brasileiros, particularmente os amazônicos. Aoutorga, aos países latinoamericanos, do Consenso de Washington, um documento que impunha aos retardatários a obrigação de adotar medidas destinadas a proteger os interêsses do Sistema pela proteção dos interêsses dos grandes países capitalistas, tornou-se uma bíblia de ação para govêrnos privatistas, como, no Brasil, o de Fernando Henrique Cardoso, que entregou ao Capital um patrimônio do povo - a CVRD - em condições nada menos que imorais. A reformatação da economia brasileira se deu ao sabor da reordenação da economia mundial explorando uma fragilidade histórica que aponta na direção da livre e sôlta rapina das suas riquezas naturais e do patrimônio do seu povo.

Uma fragilidade histórica do Brasil, por excelência, é ser êle um zero à esquerda em Ciência e Tecnologia. Êle não possui domínio de qualquer tecnologia expressiva, e isso produz uma subserviência mercenária do seu empresariado e dos seus políticos ao poder econômico externo que reforça as tendências produtivas ditadas por essa fragilidade. Um país assim permanece condenado, para sempre, a depender dos ditames presentes no Mercado Mundial pelos países que detém hegemonia científica e técnica, porque nenhuma condição (científica e técnica) de defesa possui para se contrapor a elas. Dêste modo, tem que reduzirse a obedecer às injunções impostas pelo Mercado, devido à sua dependência de conhecimento 
científico, e ausência de domínio técnico. Nessa situação, um país que possua territórios ou riquezas naturais abundantes acaba sendo forçado, pelo Mercado, a colocá-los à disposição da produção mundial em situação de desvantagem. É o caso brasileiro. Asua ausência de domínio no campo da Ciência e da Tecnologia é o resultado final da sua história pregressa, que é a própria história da sua passividade colonial e, após isso, da adoção e do cultivo de relações de produção atrasadas, que aprofundaram a sua incompetência econômica e política e a sua submissão ao poder do mercado capitalista, já agravadas por essas injunções.

Por formação histórica, a sociedade brasileira tem como elemento essencial da sua cultura a desorganização, e isso se reflete nas suas mais pequenas expressões; Por isso mesmo, no Brasil, o Capitalismo é um capitalismo anárquico e o Estado é desorganizado, na contramão de tudo o que exige o próprio sistema capitalista. Essa sua absurdez cultural é um obstáculo maior, que impede o Brasil de vencer os degraus que levam ao avanço, e faz com que êle chafurde permanente e indefinidamente no pântano do atraso. É por isso que enquanto países menos dotados e com muito mais dificuldades históricas que êle dominam circuitos científico-tecnológicos adiantados, êle continua a marcar passo, sem conseguir ir à frente. Os campos da tecnologia nuclear e espacial, por exemplo, vitais para a solução dos problemas da energia e da disponibilidade de recursos para o futuro, que qualquer sociedade que tenha planos para o amanhã encara como obrigação prioritária, são, no Brasil, simplesmente relegados ao desleixo e ao abandono pela conjunção da sua incompetência científicotécnica com a sua desorganização institucional. Assim sendo, um país que, como nós, se reduz à indigência intelectual do povo, e que se destaca por uma pavorosa violência social, detendo a maior taxa de homicídios do mundo, agora, em uma situação cada vez mais agravada pelas próprias condições da Economia Mundial Capitalista, reproduz a sua imutável tendência histórica, e, como sempre, obedece à determinação, oriunda do Mercado Mundial Capitalista, de entregar o seu território ao livre uso dêle para as finalidades da Acumulação.

Foi isso que aconteceu no percurso deste período de três décadas de govêrno civil que se sucedeu à Ditadura, e as terríveis consequências disso tinham que desabar - e desabaram exatamente sôbre a Amazônia. Após a onda privatista, pela qual um gigantesco patrimônio do povo brasileiro foi vergonhosamente entregue por um governante mercenário ao Capital, e, após essa entrega, sumido o fôlego necessário para o jôgo capitalista, o Brasil, se encolhendo cada vez mais no rumo da indigência econômica marcada pela incapacidade de levar ao mercado produtos que contivessem essência tecnológica, refugiou-se ainda mais, na incompetência, e reduziu a parcela correspondente, no seu Produto, à produção industrial, substituindo-a pela parcela, cada vez maior, da produção agrícola. O agronegócio é o refúgio útil para a incompetência produtiva do Brasil. Para alterar essa herança perversa e imutável seria necessária a vontade política para um projeto de ruptura radical com a histórica tendência pregressa do país, e com o sistema que sempre o condenou a êsse estigma - o sistema capitalista.

Para que exista um movimento ou partido verdadeiramente de esquerda são necessárias duas coisas: o apoio político das massas, e êsse projeto, um projeto de mudanças revolucionárias. Conquanto o Partido dos Trabalhadores (PT) tenha sido até hoje o primeiro e único caso histórico, no Brasil, em que um partido político deteve a adesão maciça da massa, o outro lado - o projeto revolucionário - nunca existiu com êle. A base disso é que Luiz Inácio, seu fundador e guru, é sabidamente um anticomunista ferrenho, em parte fruto da influência da Igreja, que apoiou, desde a primeira hora, no espaço político do $A B C$, o seu projeto pessoal e oportunista de ascensão política - e, em razão disso, justamente devido à postura avêssa à esquerda e anticomunista de Luiz Inácio, cuja liderança sempre impôs o tom político do PT, um possível ideário (e, por consequência, a estrutura programática) de esquerda, para o partido, foram jogados pelo ralo ainda antes mesmo que o extraordinário crescimento nacional do PT o pudesse qualificar como um partido de massa e para as massas. Isso fêz com que o PT jamais formatasse um verdadeiro projeto de enfrentamento, mas sim de convivência com o Sistema. As aparentes divergências de Luiz Inácio com o govêrno enquanto durou a sua vida de sindicalista militante, principalmente durante o período da Ditadura, criaram para o analfabetismo político brasileiro a ideia equívoca de que surgia com êle um partido de esquerda, coisa que jamais aconteceu. Por isso, o PT nunca teve um projeto revolucionário, e é isso que explica o fato de que a sua ascensão ao poder tenha sido precedida da Carta ao Povo Brasileiro, escrita por Antônio Palocci sob consulta e orientação de João Roberto Marinho, em que Luiz Inácio declara a rendição do seu projeto de govêrno - ou seja, do projeto político do PT - ao Capital Financeiro. E mais: que isto foi tenha sido antecipado por um encontro secreto, revelado pela Folha de São Paulo em reportagem de 25.11.2002, na qual foram publicados telegramas sigilosos liberados pelo govêrno dos EUA, comprovando que José Dirceu foi, em um helicóptero de Mário Garnero, ícone da ultradireita, até o edifício dêle, o Brasilinvest, no qual almoçou com a então embaixadora Donna Hrinaq, à qual pediu que fizesse saber ao govêrno do seu país que o PT não iria guinar à esquerda, e redigiu cartas pessoais tranquilizadoras, que Garnero entregou, a Richard 
Cheney, o vice-presidente de Bush, e a Ronald Evans, Secretário de Comércio. Logo em seguida ao encontro, foi apresentada a Carta ao Povo Brasileiro. Além disso, reafirmando um estilo presente em todos os exercícios anteriores de poder do PT, nenhuma medida concreta de mudança social foi levada adiante por Luiz Inácio na Presidência, exceto medidas mitigadoras, como o bôlsa-família - aliás, idéia e iniciativa da própria direita, pois nasceucom Fernando Henrique Cardoso -, destinado a ser um programa de aplacamento da fome sem jamais ser um instrumento de extinção da miséria; ainda além disso - e por isso mesmo Luiz Inácio jamais se moveu para o apoio a projetos de educação e formação de consciência popular que dariam ao povo o papel ativo de instrumento libertário - o que fêz dos beneficiados por êsses paliativos sociais apenas uma massa votante cativa, coisa que contribui perigosamente àquela velha prática histórica e secular da escória política que sempre dominou o país pela manipulação da miséria e da ignorância do povo. E ainda mais uma vez além disso, as alianças do partido e de Luiz Inácio, em busca de apoio político para a sua continuidade no poder, com o que de pior pode ser encontrado entre os políticos, no Brasil, celebrados nos quesitos corrupção e banditismo, sem que se precise declinar os nomes dêles pelo risco de se cometer uma injustiça esquecendo-se de um ou outro, mostram que o verdadeiro saldo de tudo isso, e o que se viu, em franca sintonia com a Carta ao Povo Brasileiro, foi a inteira identidade de Luiz Inácio e do PT com o Sistema, com o empresariado por natureza e tradição inimigo do povo, e em particular com o agronegócio, fortalecendo uma estratégia de indigência produtiva para o Brasil, país retardatário. Resumindo: por nunca ter tido um projeto revolucionário, o PT, quando no poder, não teve outra saída a não ser reduzir-se a praticar de forma neutra nada mais nada menos que tudo aquilo que pratica um partido político do contexto brasileiro. Inclusive - e sobretudo - a corrupção.

Assim, com o agravamento das condições da economia brasileira frente à Economia Mundial Capitalista, e com uma total incapacidade de reação ditada pelo seu atraso científico-técnico, o Brasil recuou, retrocedendo sem volta ao concentrarse na produção agrícola como refúgio da sua incompetência.

Isso resultou num avanço sem precedentes sôbre a Amazônia - mais duro, até, que o perpetrado pela Ditadura, porquanto agora é o resultado das pressões imediatas e diretas do Mercado Mundial pela ocupação territorial dela. O apossamento do espaço regional amazônico hoje está sendo determinado pari passu às necessidades manifestas pelo Mercado Mundial Capitalista. É assim que, por exemplo, a pressão crescente do mercado pela soja - o suplemento alimentar para a indústria produtora de proteína alimentar animal em regime confinado nos países avançados -, empurrou de imediato os plantadores de soja do Sul sôbre o espaço que circunda o eixo da rodovia BR-163, que liga o Mato Grosso, estado inteiramente devastado por essa atividade, a Santarém, no Pará, na embocadura do Rio Tapajós, perpetrando uma destruição terrivel da floresta amazônica da Região. E isso se deu exatamente durante o exercício de Maria Osmarina Silva como ministra do Meio-Ambiente, alçada à condição de santidade ambiental pelos parâmetros do ambientalismo burguês e pelo seu partido, a qual se manteve alheia a essa verdadeira hecatombe pelos próprios parametros do seu ambientalismo -, nada tendo feito para impedí-la. Ao mesmo tempo, aquela mágica e aquêle pas de deux orquestrado, coisas clássicas das grandes manobras imperialistas, trouxeram a Santarém a CARGILL, multinacional estadunidense que é a maior arrecadadora de grãos do mundo, que, de imediato, foi contemplada pelo poder público com todas as facilidades e privilégios para implantar-se, tomando posse de uma área da cidade que abrigava jazimentos arqueológicos cuja riqueza nem se pôde ainda avaliar com precisão, e que sem qualquer dúvida destruiu completamente, levando, junto com a sua implantação, a memória da cultura dos antigos habitantes nativos, perdida para sempre com a destruição do patrimônio arqueológico.

E assentou-se com o desrespeito total mais uma vez com a ajuda do poder público -, dos mais básicos dispositivos da legislação ambiental, já que êsse assentamento não cumpriu a exigência do Estudo de Impacto Ambiental (EIA)/Relatório de Impacto Ambiental (RIMA), e, de pronto, passou a financiar os plantadores de soja chegados do Sul, cuja produção arrecada. A transgressão flagrante que ela cometeu contra a legislação ambiental trouxe à luz uma situação ao mesmo tempo esdrúxula e reveladora, porque por duas vezes o Ministério Público conseguiu que ela fôsse interditada, o que imediatamente e por duas vezes foi revogado por tribunal, mandando que ela continuasse funcionando na sua irregularidade, mostrando como no Brasil a Justiça é uma instituição que esbofeteia-se a si mesma. Pelo seu pôrto, que tem bêrço para navios do porte PANAMAX (os navios de maior tamanho que podem passar pelas eclusas do Canal do Panamá) se escoa toda a produção de soja do devastado Planalto Santareno-Belterrense, e todas as tentativas sociais locais de sustar ofuncionamento da CARGILL esbarraram na típica imobilidade institucional que no Brasil protege os trangressores, e ela até hoje funciona ali, tendo desrespeitado as leis ambientais do país e assegurando, com a sua ação, a continuidade da destruição da Natureza provocada pelos plantadores de soja.

Êste, porém, é o menor dos males provocado pela dependência do agronegócio, nêste caso. 
mais preocupante é o que se desenha em escala muito, muito maior, para todo o Rio Tapajós. A brutal invasão da soja, apoiada pela política econômica que depende do agronegócio para as receitas externas do país, transferiu para os sojeiros, desde lá do Sul, o contrôle sôbre o destino desta área da Amazônia-a área do Rio Tapajós. Asua associação, a Associação dos Produtores de Soja e Milho do Estado de Mato Grosso (APROSOJA/MT), deseja que o Tapajós se transforme em uma via fluvial de aproximadamente 1.500 quilômetros. Atualmente só se navega no Tapajós até 350 quilômetros a partir da foz. A APROSOJA reivindica uma hidrovia para permitir o escoamento da soja desde o Mato Grosso do Sul pelo Tapajós até Santarém - e, daí, até a foz do Amazonas, a mais 800 quilômetros, mais ou menos, para o seu envio para o Mercado Mundial pelo pôrto de Santana, a cidade das prostitutasmeninas surgida como pôrto de escoamento do manganês na época da ICOMI. Os plantadores de soja já chegaram até lá, e já começaram a converter o Amapá, que até dois anos atrás era o Estado amazônico de maior integridade florestal, num espaço caótico de destruição para o plantio de grãos. E já tomaram posse da llha de Santana, onde deverá ser construído o pôrto graneleiro para êsse fim.

A razão para essa hidrovia é um projeto imperialista de contrôle continental cuja ideia surgiu há quase 200 anos atrás, e vem sendo mostrado sob as mais diversas aparências, desde a sua formulação original como um projeto de hegemonia econômica e política que pretendeu internacionalizar a Amazônia ainda no século XIX, e cuja natureza, por não ser objeto de mérito, não será discutida aqui. Mas que, recentemente, reapareceu com o nome de ALCA, um acôrdo de "livre" comércio que os Estados Unidos tentaram empurrar para os países da América Latina, e que, embora por pouco não tenha sido acolhido e aceito, no Brasil, pela subserviência canina de Fernando Henrique, foi rejeitado, como projeto imperialista, pelos movimentos sociais latinoamericanos. Como a intenção contida nêle é (sempre foi) estratégica para os Estados Unidos, caso êle seja rejeitado pelos movimentos sociais do continente sempre há uma segunda via dêle pronta para ser posta em prática. Assim, os EUA encarregaram Vicente Fox, então presidente do México, de tentar pôr em ação, como projeto-pilôto, um outro, que era a mesma coisa, batizado como Plano Puebla-Panamá, eque envolvia os estados do sul do México e os países da América Central. Êste também foi rejeitado pelos movimentos sociais indígenas daquela região. Mas ainda para o caso de êste ser rejeitado, êle já estava, de novo, pronto sob um novo rótulo - Iniciativa de Integração da Infraestrutura Regional Sul-Americana (IIRSA) -, que era a mesma coisa que os demais, montado sôbre um modêlo de ocupação de espaço e expulsão das populações nativas - indígenas ou mestiças -, das suas terras, as quais deveriam ser ocupadas sobretudo por grandes barragens, alegando-se a criação de uma rêde hídrica que serviria ao desenvolvimento local - mas que, na verdade, é um complexo para a produção de energia e transportes destinado à ocupação capitalista do território. Vale dizer que êsse mesmo projeto havia sido apresentado à Pan-Amazônia durante a Ditadura Militar brasileira como o famoso Projeto dos Grandes Lagos Amazônicos, rejeitado até por segmentos ligados ao Golpe e a Ditadura, que viam nêle um perigo à soberania nacional pela perda de contrôle do espaço amazônico, no caso do Brasil.

Fernando Henrique, como era de se esperar, tentou implantar o IIRSA com o Avança Brasil. Mas, reiterando a constatação de que o PT foi muito mais competente que o Partido da Social Democracia Brasileira (PSDB) em formatar - Estado brasileiro como Estado neoliberal, Luiz Inácio abrigou o IIRSA no Brasil sob o Programa de Aceleração do Crescimento (PAC). O programa de construção de hidroelétricas que começou com êle e que se disseminou epidêmicamente com a invasão da soja e a cantiga do desenvolvimento tem todos os contôrnos do modêlo, desde as razões alegadas no século XIX para tentar internacionalizar a navegação no Amazonas e colonizar a Amazônia à base da fôrça de trabalho escrava do Sul dos EUA, até a sua mais recente versão, a do IIRSA, montada sôbre a lógica das multinacionais. A integração da Amazônia a partir do govêrno do PT é aliada de tudo o que o Imperialismo pensa e planeja para a Região.

$E$ isso é ajudado pelas evidências que desmentem a pretendida natureza de esquerda ou social do PT e do seu criador e o seu governo, que enquanto se recusa - contra o seu discurso histórico - em pôr em prática medidas ou projetos que desenvolvam o esclarecimento, a consciência política e a organização popular, toma medidas que aumentam a capacidade repressora do Estado. Govêrnos de esquerda visam prioritàriamente o bemestar e o crescimento intelectual do povo; govêrnos de direita vêem o povo com cautela, praticam um paternalismo autoritário, ou simplesmente o tratam como inimigo. Luiz Inácio, como já se viu, jamais sequer esboçou a intenção de realizar programas populares concretos de educação, cultura e organização popular como prioridade; mas tomou, como uma das primeiras medidas do seu govêrno, a criação da Fôrça Nacional de Segurança, medida típica de govêrno autoritário, aprimorando a repressão desenvolvida pela Ditadura, que estruturou a Polícia Militar (PM) como instrumento da manutenção da ordem pública através da violência. A Fôrça Nacional de Segurança seleciona os seus quadros com o que de melhor existe entre as PMs estaduais, dando ao Estado um poder de reação imediata contra qualquer protesto social 
pelo aprofundamento da já elevada capacidade repressora da PM. Ora, só aprimora o poder de repressão da polícia - e no Brasil a polícia já é, por natureza, uma corporação violenta - um Estado que funciona como instrumento de dominação de classe, não um Estado voltado à causa popular. Assim, se Luiz Inácio escolheu essa opção, o seu govêrno e do seu partido são tudo menos um govêrno que coloca o Estado a serviço do povo. E isso fica claro quando índios, cabôcos e nativos em geral tentam resistir aos projetos de desenvolvimento do PAC que se destinam a assegurar a ocupação capitalista da Amazônia: são imediatamente desencorajados pela brutalidade repressora da Fôrça Nacional de Segurança, como já aconteceu, principalmente, na obra do Belo Monte, em Altamira - Fôrça essa que é obra exclusiva e acabada de Luiz Inácio da Silva, seu idealizador e executor.

Por fim, por extenso que seja êste trabalho, ainda cabe aqui uma consideração essencial, que, discutindo a resistência à agressão ao patrimônio natural - que é social - e ao povo, seu verdadeiro dono, deve servir como exemplo à necessidade de acordar contra as solertes estratégias da rapina. Um caso ocorrido há alguns anos no Baixo-Amazonas, envolvendo mais um dos inúmeros Grandes Projetos da Amazônia, deve servir como êsse exemplo, e é imperativo que seja exibido como tal.

No Capitalismo, todo projeto mineiro é projetado para durar, no máximo, umas poucas décadas, por maiores que sejam as jazidas assaltadas. Exaurido, passa-se para outro, após sugar-se até a última gota a sua capacidade de dar lucro. É a lógica do Capital. Fica para trás a terra arrasada - mas leva-se o lucro como o resultado da terra que se arrasou e das riquezas que se arrancaram dela. Dêste modo, assim como o manganês do Amapá durou pouco mais de 30 anos, assim também a bauxita do Trombetas, com pouco mais de três décadas, já começa a dar sinais de ingresso na fase de exaustão. É hora do Capital buscar outras fontes para saquear, pois é isto que garantea sua existência. Eumadessas fontes estava, até bem pouco, guardada, apenas esperando o momento de ser acordada para ser explorada. Era a bauxita do município de Juruty, que, logo que a mina do Trombetas deu os primeiros sinais de entrada em exaustão, passou a ser o alvo da nova ação mineira. Uma multinacional do ramo do alumínio dos EUA, a ALCOA, começou a montar um projeto para assaltá-la. E os movimentos sociais do entôrno, pelo o barulho e pela movimentação que surgem ao começar a se preparar um empreendimento como êsse, começaram a ser acordados para a chegada dêle

O Imperialismo não tem nem amigos nem adversários; a sua tendência é converter aquêles que pretendem ser seus amigos em seus serviçais ou seus cachorros. Os que pretendem ser seus adversários, êle sempre tende a convertê-los em inimigos e eliminá-los - ou, se possível, corrompêlos, fazendo dêles novos cachorros ou novos serviçais através da corrupção.

A Justiça é um importante pilar de qualquer sistema. E como na sociedade capitalista os valores do sistema se repassam das sociedades hegemônicas às sociedades caudatárias, é muito comum que as noções e conceitos que orientam os valores e os ritos da Justiça, que se originam nas sociedades hegemônicas, sejam repassados por elas às sociedades caudatárias. Como a Justiça adota conceitos e princípios que estão consagrados como valores sociais, é sempre frequente que conceitos criados em outras sociedades segundo a lógica do sistema capitalista sejam elementos orientadores da Justiça nas sociedades retardatárias. Alguns dêsses valores dizem respeito a problemáticas incapazes de serem resolvidas na sua essência porque são contradições que fazem parte da própria essência constitutiva do sistema capitalista, sôbre as quais repousa a própria estrutura dêle. Para resolver essas contradições, - sistema produz formulações ideológicas cujo papel é fazer de conta que elas são resolvíveis, quando, na verdade, não o são. Três delas são as apresentadas sob os rótulos do Meio-Ambiente, dos Direitos Humanos, e das Minorias, cuja solução é impossível no contexto capitalista devido à própria natureza das relações de produção do sistema. Para compensar essa impossibilidade, se engendram ficções legais que remetem a solução delas a outras instâncias, criando compensações para balancear essa impossibilidade na esfera ideológica. A Justiça é a mais importante dessas instâncias porque tem o poder de criar compensações legais; e assim, muitos dos seus ritos se tornam mecanismos dessa compensação. E como as sociedades hegemônicas repassam os conceitos, valores e princípios âs sociedades retardatárias, assim também repassam a elas êsses ritos, porque êles fazem parte da lógica que comanda a Justiça nas sociedades do Capital.

Dois dos ritos mais privilegiados para a solução das controvérsias dessas problemáticas são as audiências públicas e o Têrmo de Ajustamento de Conduta (TAC). A primeira destina-se a simular que haja pêso de voto do povo em decisões críticas sôbre projetos controversos que têm efeito sôbre êle, o povo, quando, na verdade, essas decisões já estão tomadas de antemão nos circuitos do Poder, e sempre obedecem ao interêsse do Capital. O rito, então, tem a finalidade de produzir um simulacro de processo democrático que esconde a real estrutura invisível da tomada de decisão, fazendo com que pareça real a ficção de que a vontade do povo pesa decisivamente no resultado final (no qual sempre pesa a manifestação de pessoal local que a emprêsa sempre arrebanha para apoiá-la). O segundo é decorrência da primeira, porquanto essas 
audiências existem para que o povo nunca perca: a emprêsa é sempre condenada, por um TAC, a indenizar o povo pelos danos causados contra êle pelo projeto que não era bem-vindo. Como êsse é um mecanismo montado à perfeição pela lógica do Sistema e essa indenização já está prevista como um custo (financeiro) operacional do projeto, o TAC sempre acaba por ser uma espécie de taxaesmola, a ser paga - alegremente - pelo autor do estupro, para que a vítima, uma vez indenizada, não possa recusar-se a ser estuprada. E o que é pior: isso funciona às mil maravilhas nas cabeças dos que lidam com a Lei, quer para os sevandijas, que sabem muito bem como isto funciona e porquê, quer para os nefelibatas, que acreditam piamente estar defendendo, com essas medidas, a causa e o bemestar do povo.

No caso de Juruty, a decisão de resistir ao projeto da multinacional foi assumido por um grupo que havia sido convidado, pela freira Fátima Paiva, da congregação das Franciscanas de Maristela da vila do Juruty Velho, para discutir o Projeto. Êsse grupo enxergava no projeto da ALCOA mais um dos inúmeros casos de rapina que se repetem indefinidamente na Amazônia, e previa que já no seu assentamento chegariam com êle as práticas da corrupção, próprias do sistema capitalista, que não podem se dissociar dêsse tipo de empreendimento e que se instalariam no meio contaminando todas as esferas institucionais como seu subproduto próprio. Por isso, decidiram tomar a decisão de resistir - se nada mais fôsse, como exemplo de luta -, coisa que logo entrou em choque com a freira, que após a idéia inicial de enfrentara multinacional, se encantou com a proposta trazida por um promotor estadual, Raimundo Morais, que se ajustava, ponto por ponto, à lógica e ao esquema que envolve a adoção da audiência pública como fórum da participação popular e a imposição do TAC como instrumento de correção da injustiça e coincidia com a disposição do govêrno do Pará (um Estado riquíssimo em recursos naturais, mas, por isso mesmo, enfraquecido pelo efeito conjugado da Lei de Responsabilidade Fiscal e da Lei Kandir - dois dispositivos cuja conjunção é destinada a debilitar Estados que tenham grandes e ricos recursos naturais para que possam ser saqueados sem o mínimo esfôrço) em procurar novas fontes fiscais, não importando que a arrecadação aí se fizesse às custas da perda de uma riqueza natural tão incalculável quanto insubstituível, coisa que movia a disposição de resistir do grupo rebelde. A alegação do promotor servia como uma luva aos interêsses da rapina, e era tão simplista quanto solerte: se êles querem explorar a riqueza que está no solo de uma comunidade nativa, nada mais justo que paguem por isso. Um discurso assim, e num tom tão melífluo, encanta a emprêsa predadora, porque foi exatamente para ela e para êsse seu fim - a rapina - é que foi criado êsse tipo de argumento.
A essa altura, Juruty já ingressara no frenesi dos discursos do desenvolvimento, e o prefeito Henrique Costa, do PT, já tinha tomado a providência de aderir ao progresso do município (e, pois, ao projeto da multinacional) logo na primeira hora. A ignorância do meio foi ràpidamente manipulada pela máquina ideológica controlada pela emprêsa e pelo poder local, a militância do PT e dos movimentos sociais ligados a êle, demonstrando um exemplar analfabetismo político proposital e sectário uniu-se em pêso para apoiar o empreendimento, usando daquela confusa mistura ideológica que junta a cantilena do progresso com a alegria pelas vantagens que a multinacional seria obrigada a trazer; e a cúpula da oposição ao Projeto, comandada pela freira Fátima, ficou formada, além dela, pelo promotor Raimundo Morais, mentor ideológico do argumento, e pelo advogado Dilton Tapajós, assessor dela. A partir daí, constatando, satisfeita, que as coisas tinham tomado o rumo calmo e certo que deviam, a emprêsa logo ajudou a estruturar um circo de três audiências públicas uma em Juruty, uma em Santarém e uma em Belém - às quais enviou uma enorme massa de torcedores vestindo camisas mandadas confeccionar por ela, contendo os emblemas dela e da prefeitura local, em navios fretados por ela com mesas (e bebida) fartas à disposição dos participantes, que aplaudiam, entusiasmados e frenéticos, qualquer defesa do Projeto. Mais uma vez, a audiência publica funcionava à perfeição, conforme fôra idealizada pela WDC, a Comissão Mundial de Barragens (CMB) do BM, mentora dessa farsa. Assim, já na segunda audiência, o grupo que resistia, cuja postura prejudicava a oposição que buscava o entendimento, e que era visto como radical ou guerrilheiro por essa oposição, estava excluído e não mais participou do resto doprograma.

Como não podia deixar de ser, o caso seguiu os contôrnos previstos, pois antes mesmo da implantação do Projeto, e dado que era certa a sua chegada, já se havia tomado a providência de fundar uma associação das comunidades da região do Juruty Velho, a ACORJUVE, para cuja presidência foi eleito Gerdeonor Pereira Santos, uma liderança jovem do meio, militante das atividades coordenadas pela freira Fátima. E assim, com a entrada em funcionamento da mineração, a prefeitura municipal e a ACORJUVE, cada uma na sua esfera de competência, passaram a receber os pagamentos feitos pela emprêsa, que também se tornou a virtual dona de Juruty, e para a qual o executivo local desapropriou todas as terras que fôssem de interêsse do projeto.

À parte as providências associadas à infraestrutura - asfaltamento de ruas, escolas, hospitais - indispensáveis ao funcionamento de um empreendimento como êsse - mas apresentadas como os primeiros benefícios do Projeto -, logo 
se instalou em Juruty tudo aquilo que acompanha as transformações radicais provocadas por êsses tumores: um crescimento explosivo em menos de uma década, o surgimento de delitos e crimes até então inexistentes, próprios das áreas urbanas, e - como havia sido previsto pelos rebeldes - a modernização das inevitáveis brigas da politicaria local. Surgiram logo as indefectíveis denúncias de corrupção, e um dos primeiros alvos delas foi logo o prefeito Henrique Costa, acusado de enriquecimento vertiginoso e inexplicável que transparecia em coisas tais como a sua nova e suntuosa residência, assim como pela sua súbita conversão em empresário, por ter-se tornado sócio de uma emissora de TV.E, nisso tudo, um traço digno de nota é que o empresariado local, que havia sido uma destacada fôrça de apoio à chegada da multinacional, prevendo, naquela mistura de esperteza do empresário e estupidez do provinciano, as grandes vantagens que ela traria para êles, foi relegado, depois dos seus investimentos em instalações e estoques, às dificuldades de mercado e até, em alguns casos, à falência, pois a emprêsa passou a comprar virtualmente tudo fora do comércio local, o que fêz com que êles passassem, em relação a ela, da admiração eufórica à inimizade. Recado claro: a emprêsa multinacional tinha o poder de dar as ordens. O meio local, de obedecê-las.

$\mathrm{Na}$ esfera da ACORJUVE, foi apenas uma questão de tempo para que as coisas passassem a exibir o mesmo tom. Como representante dos moradores das áreas atingidas pelo assentamento da mineração, a ACORJUVE passou a receber enormes somas de dinheiro - pífias para os cofres da emprêsa, mas muito grandes para o meio. As estimativas eram de que entre 2007 e 2014 tenham sido repassados a ela ao redor de 28 milhões de reais, o que demandava a formação de uma instância competente, dentro dela, para administrar essas finanças - e foi formada uma assessoria, da qual passaram a participar o advogado e assessor da freira e o sociólogo Everaldo Portela, professor da Universidade Federal do Oeste do Pará (UFOPa), entre outros.

No entanto, além disso havia uma outra fonte de recursos, oriunda da madeira retirada da área a ser minerada, coisa de alguns milhões de reais, além de um outro aporte, da parte do Instituto Nacional de Colonização e ReformaAgrária(INCRA), para a construção de casas para os nativos da área, cifra igualmente milionária, a ser administrada pela ACORJUVE. Logo os jornais de Santarém passaram a estampar matérias questionando o destino de um expressivo montante de recursos, focando o presidente da Associação, que, aliás, até aqui encontra-se no cargo em virtual condição ad perpetuam durante os mais de dez anos de vida dela. À parte, porém, o flagrante sensacionalismo dos jornais locais, o clima de bate-bôca que se instalou a partir daí, envolvendo êsses jornais e representantes da Associação e denunciantes deixa no ar a sensação de que aquela síndrome dos casos sem nitidez - acusações de um lado, contra-ataques do outro, e um limbo de contôrnos imprecisos -, já tenha contaminado por completo o meio local. De qualquer modo, e como haviam previsto os rebeldes, a corrupção que havia acompanhado a chegada e a implantação do Projeto penetrara como uma praga corrosiva e pestilenta nas relações sociais locais para emoldurar de modo adequado o tema principal - a rapina sobre um riquíssimo patrimônio natural que nunca mais retornará para lá.

Como, nêsse meio-tempo, a freira Fátima tinha buscado apoios para isso que ela e os discursos da ACORJUVE têm apresentado, em diversas ocasiões, como uma Luta contra o Imperialismo - coisa gargalhável, para dizer o mínimo - várias foram as pessoas e, mesmo, movimentos sociais, que, ou por desaviso ou por pura ignorância política - ou, mesmo, proposital e conscientemente -, deram apoio a essa luta. E como, devido às relações entre a CPT Regional com a Fundação Ford - a organização do grupo Ford que financia projetos de pesquisa nos espaços sociais retardatários e que é, assim como o BM, um elemento importante para o jôgo do Imperialismo e sempre está por perto dos grandes projetos das grandes emprêsas que atuam nêsses espaços - como a Fundação demonstrou interêsse em conceder recursos para as atividades da Irmã Fátima, a então coordenadora da CPT Regional, Jane Silva, passou a articular o apoio dos movimentos sociais ao projeto da freira - e, na sequência de um evento que acontecera em Santarém, militantes de vários dêsses movimentos presentes ao mesmo, inclusive alguns do próprio Movimento dos Trabalhadores Sem-Terra (MST), ignorando a presença local da CPT do BaixoAmazonas, que sempre apoiou a resistência e o enfrentamento com o projeto da ALCOA, e passando por cima dela e do seu coordenador, o Padre José Côrtes dos Reis Antunes, viajaram até Juruty para prestar solidariedade a essa escolha política que, ao invés de rejeitar a multinacional rapineira, celebrou com ela, em nome da defesa de um meio social por direito dono de um patrimônio natural, um entendimento que, em seu resultado final, assegurou não só a pilhagem de uma riqueza que jamais será recuperada, como, também, produziu, como seu subproduto próprio, a perversão moral - pela epidemia de corrupção que chegou com o Projeto - do meio social em que havia a riqueza predada. A quota distribuída pela ACORJUVE a cada um dos associados, oriunda do pagamento que a emprêsa de rapina faz ao meio social, girava, em janeiro de 2011, segundo uma moradora do distrito do Muirapinima, entre 650 e 950 reais mensais. Ou seja: cada morador nativo das áreas atingidas pela mineração recebe, através da associação beneficiada pelos têrmos do TAC, um valor que gira 
ao redor do indecente salário pago, no Brasil, a um trabalhador sem qualificação. Essa é a justa paga que restou das previsões do promotor Raimundo Morais, cujas alegações diziam defender os direitos dos simplórios nativos convencidos pelo discurso a acreditar que era vantajoso permitir que um animal de rapina invadisse a terra dêles para abocanhar a enorme riqueza que arranca de lá.

Tem havido, daparte daACORJUVE e dasua assessoria técnica, uma crescente pressão sôbre a Emprêsa, sob a acusação de que ela é imperialista, e exigindo dela o cumprimento de acêrtos não honrados, o que de algum modo, pareceria condizer com a Luta contra o imperialismo da freira Fátima e da Associação; no entanto, pessoas da área, ligadas ao problema e à militância social, têm levantado a hipótese de que, ao contrário, não há qualquer objetivo de que a Emprêsa saia dalí (coisa, por sinal, impossível) - o que, por consequência, implica a continuidade da rapina -, porque o que essa estratégia em verdade pretende é que sejam aumentadas ainda mais as contribuições e os repasses que a Emprêsa já transfere, hoje, aos seus opositores - o que valeria dizer que essa Luta contra o imperialismo acabaria por ser apenas uma ação entre amigos pela busca de vantagens materiais privadas obtidas de um inimigo. Opositores assim jamais iriam querer que desapareça um sistema como êste.

Dois acontecimentos recentes somam um fio de estranheza sôbre todos êsses fatos: o primeiro é a quase certa chegada de mais um empreendimento dêsses, para explorar uma jazida igualmente preciosa, mas muito maior (duas vêzes os um bilhão e cem milhões de toneladas da jazida do Trombetas), pela multinacional Rio Tinto Zinc, na área limítrofe entre Alenquer e Monte-Alegre, o que já provocou um clima antecipado de disputas entre êsses dois municípios pela propriedade da jazida, a qual só ainda não foi posta em exploração por estar em uma área de proteção ambiental - impecilho que, mais dia menos dia ,sem dúvida alguma deverá ser resolvido. Há a notícia de que o assessor da freira Fátima já esteve na área cadastrando os moradores nativos, com vistas à perspectiva de uma nova oposição, o que, se acontecido, teria as mesmas consequências, já suficientemente comprovadas, de Juruty. O segundo são as denúncias, por várias pessoas, de terem sofrido ameaças por terem denunciado irregularidades que teriam sido cometidas na administração da ACORJUVE. São dois casos emblemáticos que somam, de um lado, a sensação de que o saque sôbre a Amazônia sempre irá se repetir com a ajuda dos que são daqui mesmo, e que, sempre que preciso, se levantam, unidos, para entregar as riquezas da terra ao Capital; e, de outro, que tantas vêzes quantas se erguer a resistência a essa entrega, os que se ousarem a isso serão alvos da ira e da maldição daquêles que o Capital perverte e torna santos a essa dimensão.
Recentemente têm surgido comentários, em caráter reservado, de que o promotor estaria preocupado não só com uma já esboçada intenção de serem mudados os estatutos da ACORJUVE para permitir que possa ser possível a recondução ao cargo do atual presidente por tempo indeterminado, bem como da sua preocupação com uma postura que a assessoria técnica da Associação tem demonstrado sôbre os recursos oriundos da madeira retirada do local, e que - pelo mencionado - já teria, inclusive, envolvido tratativas com madeireiros, interessados nela. $O$ que torna jocosos casos como êsse - se se pudesse tomá-los apenas como jocosos - é que os aprendizes de feiticeiro costumam se surpreender quando se dão conta de que as criaturas geradas por êles saíram do contrôle -, e passam a remeter aos azos do destino a culpa pelo insucesso das suas mais santas intenções.

\section{CONCLUSÃO}

É preciso que se tenha a consciência da necessidade de perder a inocência, no seu bom sentido, como o fêz ao povo cubano a sua Revolução. Sem unidade política não se leva adiante qualquer projeto de libertação popular - e a perda da inocência é o primeiro passo para formar essa unidade. Para que se possa assegurar a ruptura com o Capitalismo - sistema corrompido e corruptor - tão necessária a um projeto social libertário, é preciso, urgentemente, um projeto de perda da inocência, que nos liberte não só da ingenuidade que nos faz entregar, pacificamente e sem perceber, o patrimônio do povo aos predadores do Capital, como dos traidores que se travestem de companheiros para que melhor possam ser traidores. O esvaziamento e a desmobilização do MST pelos efeitos do Bôlsa Família é uma das mais amargas provas de como o Brasil é uma realidade social em que convivem o desespêro amargo de um povo sem renda com a fragilidade dos seus movimentos sociais. E enquanto não se tiver a consciência da necessidade de enfrentar sem trégua a perversão social que o Capital engendra, estaremos sempre no lado equívoco dos que pensam - ou do lado solerte dos que alegam - estar do lado do povo. Não custa parafrasear a lucidez de um guerrilheiro das Forças Armadas Revolucionárias da Colômbia - Exército do Povo (FARC-EP) entrevistado por um jornal brasileiro: a política é mais dura do que a guerra. Um êrro no campo de batalha pode custar a perda de uma vida. Mas um êrro político pode custar a vida de todo um projeto político. (Informação verbal) ${ }^{1}$.

\section{NOTAS}

${ }^{1}$ Foram utilizados outros materiais como jornais, revistas e publicações diversas do período de 1970 até hoje, e jornais de Santarém, a partir de 2005. 
2 Para o melhor entendimento dêste texto, recomenda-se, entre outras, o exame das seguintes obras: ACKERMANN, F. L. Recursos Minerais do Território Federal do Amapá. Rio de Janeiro: Imprensa Nacional, 1948; AKERS, C. E. Relatório sôbre a indústria de borracha no Oriente. [S. I.: s. n.], 1912 AKERS, C. E. The Rubber Industry in Brasil and the Orient. London: Methuen \& Co, 1914; BANDEIRA, M. Presença dos Estados Unidos no Brasil. Rio de Janeiro: Civilização Brasileira, 1978. (Coleção Retratos do Brasil, v. 87). BASTOS, A. C. T. O Valle Do Amazonas: a livre navegação do Amazonas, estatistica, producções, commercio, questões fiscaes do Valle do Amazonas. São Paulo: Companhia Editora Nacional, 1937. (Série Brasiliana, v. 106); BIONDI, A. GONZALES, L. O que há por trás de Carajás. In: Século XXI (fotocópia). [S. I.: s. n.]; BUARQUE, M. O Amapá: Altamira, Pará, 1920. Belém: Papelaria Suisso, 1925; CARNEIRO, G. Jary: uma responsabilidade brasileira. São Paulo: Ed. LISA, 1988; CASANOVAS R. B. El Imperio del Caucho: perfil del noroeste boliviano. La Paz: Imprenta Y Librería "Renovación", 1984; COATES, A. The Commerce in Rubber: the first 250 years. New York: Oxford University Press, 1987; COHEN, J. Ford-Landia: a grande interrogação do futuro. Belém: [s. n.], 1929; COIMBRA, C. A Revolução de $\mathbf{3 0}$ no Pará: análise,crítica e interpretação da história. Belém: Conselho Estadual de Cultura, 1981. (Coleção História do Pará, Série Arthur Vianna); COLLIER, R. Jaque Al Barón: la historia del caucho en la Amazonia. Lima: Centro Amazonico de Antropología Y Aplicación Pratica, 1981; COMBLIN, J. $P$. A Ideologia da segurança nacional: o poder militar na América Latina. Rio de Janeiro: Civilização Brasileira, 1980; COYNE; BELLIER. Large Artificial Lakes: Rio Ucayali. Paris: Draft, Coyne \& Bellier, 1969; COYNE; BELLIER. The damming of the Amazon in the Santarém Region. Paris: Draft, Coyne \& Bellier, 1968; CRAIG, N. B. Recollections of an ill-fated expedition to the headwaters of the Madeira River in Brazil. Philadelphia: J. B. Lippincott, 1907. In Cooperation with members of the Madeira and Mamoré Association of Philadelphia; CRULS, G. Impressões de uma visita à Companhia Ford Industrial do Brasil.Revista Brasileira De Geografia, Rio de Janeiro, ano I, n. 4,out. 1939; CUNHA, A. da. Quem explorou quem no contrato do manganês do Amapá. Macapá: Editora Rumo, 1962. DANTAS, M. Carajazão entusiasma capital estrangeiro. Relatório Reservado, [S. I.], v. 13, n. 697, p. 1, 1980a; DANTAS M. O Carajazão. Relatório Reservado, [S. I.], v. 14, n. 732, p. 3, 1980b; DREIFUSS, R. A. 1964: a conquista do Estado - ação política, poder e golpe de classe. Petrópolis, RJ: Vozes, 1981; ELETRONORTE. Eletronorte: 100.000.000 kw. Brasília, DF, [20--?]; FIGART, D. M. The Plantation Rubber Industry in the Middle East. Washington, D. C.: The Government Printing Office, 1925; GOVÊRNO DO TERRITÓRIO FEDERAL DO AMAPÁ. O Manganês da Região do Rio Amaparí: ligeiro histórico do aproveitamento. Macapá: Imprensa Oficial, 1951; INDÚSTRIA E COMÉRCIO DE MINÉRIOS. O Manganês do Amapá.Macapá, [20--?]; INTERNATIONAL DEVELOPMENT CENTER OF JAPAN. IDCJ. Tokyo, [20--?]; INTERNATIONAL INSTITUTE OF SYNTHETIC RUBBER PRODUCERS. Synthetic Rubber: the history of an industry. New York, 1973; KAHN, H.; PANERO, R. New focus on the Amazon. New York: The Hudson Institute, 1965; KRAVIGNY, F. W. The Jungle Route. New York: Olin Tremaine, 1940; LEAL
FILHO, A. Reserva Nacional para a Defesa de Carajás. Relatório Reservado, [S. I.], v. 15, v. 775, p. 4, 1981; LEAL, A. L. A ICOMI e o Manganês do Amapá. [S. I.: s. n.], 1996. Inédito; LEAL, A. L. Amazônia: o aspecto político da questão mineral. 1988. Dissertação (Mestrado) Universidade Federal do Pará, Belém, 1988; LEAL, A. L. 0 Projeto Ford do Tapajós. [S. I.: s. n.], 1996. Inédito; LEAL, A. L. Os primeiros impactos sociais de um polo metalúrgico na Amazônia: o caso Albrás/Alunorte. Ciências da Terra: revista da Sociedade Brasileira de Geologia, n. 5, jun./jul. 1982; LEAL, A. L. Uma sinopse histórica da Amazônia. São Paulo: [s. n.],1991. Datilografado; LEONARDOS, O. H. O problema brasileiro do manganês. Engenharia, Mineração e Metalurgia, Rio De Janeiro, v. 26, n. 155, p. 271-272, nov. 1960; LOPEZ, C. T. Las maravillosas tierras del Acre: en la Floresta Amazonica de Bolivia. La Paz: Talleres Tipograficos del Colegio D. Bosco, 1930; LUZ, N. V. da. A Amazônia para os negros americanos: as origens de uma controvérsia internacional. Rio de Janeiro: Ed. Saga, 1968; McFADYEAN, A. The History Of Rubber Regulation 1934-1943. New York: W. W. Norton \& Company, [20--?]; MEIRA MATOS. Uma geopolítica PanAmazônica. Rio de Janeiro: Biblioteca do Exército Editora, 1980; MINERAÇÃO RIO DO NORTE. Relatório Anual de 1975. [S. I.: s. n.], 1975. Projeto Trombetas. MINISTÉRIO DAS MINAS E ENERGIA. Departamento Nacional da Produção Mineral. Código de Mineração e Legislação Correlativa. Ed. rev. Brasília, DF, 1980; MOREL, E. Amazônia Saqueada. São Paulo: Global Editora, 1989; MYERS, J. G. Fordlandia: the settlement on the Ford Rubber Concession in Brazil. The Tropical Agriculturalist Journal Of Ceylon, [S. I.], v. LXXXIII, n. 1 to 6, p.168-171, jul./dec. 1934; OLIVEIRA, E. R. de. As fôrças armadas: política e ideologia no Brasil (1964/1969). Petrópolis, RJ: Vozes, 1976; ORTON, J. The andes and the amazon, or across the Continent Of South America. Harper and Brothers Publishers, New York, 1870. PAIVA, G. de. Relatório sumário da visita feita aos depósitos de manganês da Serra do Navio e Cercanias, no Rio Amaparí (Datil). Macapá, 1946. PANERO, R. A South America great lakes system: preliminary report. New York: The Hudson Institute, 1967; PANERO, R. The Amazon: a catalytic approach to development. New York: The Hudson Institute, 1972; PINTO, N. P. A. Política da borracha no Brasil: a falência da borracha vegetal. São Paulo: Hucitec, 1984; RAMOS, C. R. Manganês. Boletim do DNPM, Brasília, DF, 1984; RAMOS, C. R. Perfil Analítico do Alumínio. Boletim do DNPM, Brasília, DF, n. 5, 1982; REALIDADE. Realidade Amazônia, São Paulo, v. 179, ed. esp., out. 1971; REIS, A. C. F. A Amazônia e a cobiça internacional. Rio de Janeiro: Civilização Brasileira, 1982; RETRATO do Brasil. Coletânea. 4 v. São Paulo: Editora Política, 1984; SANTOS, B. A. dos. Amazônia: potencial mineral e perspectivas de desenvolvimento. São Paulo: T. A. Queiroz/USP, 1981; SAUTCHUK, J.; CARVALHO, H. M.; GUSMÃO, S. B. Projeto Jary: a Invasão Americana. São Paulo: Ed. Brasil Debates, 1980; SCHURZ, W. L. et al. Rubber production in the Amazon valley. Trade Promotion Series, Washington, D. C., n. 23, 1925; SUPERINTENDÊNCIA DO PLANO DE VALORIZAÇÃO ECONÔMICA DA AMAZÔNIA. Amazônia: nôvo universo. Belém: SUDAM, [20--?]. Ed bilingue; SUPERINTENDÊNCIA DO PLANO DE VALORIZAÇÃO ECONÔMICA DA AMAZÔNIA. Primeiro Plano Quinquenal de Desenvolvimento 1967/1971. Belém: SUDAM, 1967; TOSTA, O. Teorias Geopolíticas. Rio de Janeiro: Biblioteca do Exército Editora, 1984. (Coleção General Benício, v. 225).

Informações retiradas de uma reportagem do jornal 
Esconderijo das Farc na selva da Colômbia vive expectativa e paz do Jornal Folha de São Paulo.

\section{Aluizio Lins Leal}

Economista

Doutor em História Econômica pela Universidade de

São Paulo (USP)

Professor aposentado da Universidade Federal do

Pará (UFPA)

E-mail: lins@ufpa.br

Universidade Federal do Pará - UFPA

Instituto de Ciências Sociais Aplicadas - Avenida

Augusto Corrêa, 01 - Guamá

CEP: 66075-110 